\title{
A SURVEY ON SEVERAL POTENTIALLY PROBLEMATIC AREAS OF PRONUNCIATION FOR IRANIAN EFL LEARNERS
}

\author{
Amir Toghyani Khorasgani \\ Young Researchers Club, Khorasgan Branch, Islamic Azad University, Isfahan, Iran \\ Email: toghyaniomid@yahoo.com
}

Ali Toghyani Khorasgani

Ph.D. Student in the field of Curriculum Planning and Young Researchers Club, Khorasgan Branch, Islamic Azad University, Isfahan, Iran

Email: alitoghiyany@yahoo.com

Narges Keshti Aray

Assistance Professor at Islamic Azad University, Isfahan, Iran

Email: n_keshtiara@khuisf.ac.ir

APA Citation. Khorasgani, Khorasgani \& Aray (2015). A survey on several potentially problematic areas of pronunciation for Iranian EFL learners. Indonesian EFL Journal, 1(2), 189-198

Received: 02-04-2015

Accepted: 24-04-2015

Published: 01-07-2015

Abstract: Almost all English language teachers get students to study grammar, vocabulary, etc., but some of these same teachers make little attempt to teach pronunciation in any overt way and only give attention to it in passing. Pronunciation teaching not only makes students aware of different sounds and sound features, but can also improve their speaking. Concentrating on sounds, making aware of where words should be stressed, where words made in mouth, give students information about spoken English and help them achieve the goal of improved comprehension and intelligibility. Pronunciation forms a natural link to other aspects of language use, such as listening, vocabulary, and grammar; ways of highlighting this interdependence in teaching need to be explored. The present paper looks at the problems which Iranian learners are deal with through learning English according to the differences between their segmental and suprasegmental patterns in phonology. Comparing the Persian vowel system with that of English reveals some significant differences in the following three areas: 1) the number of vowels, 2) tense/lax distinctions, and 3) the pure/glide. There are also noticeable differences in consonantal distributions between Persian and English such as their numbers, clusters, manner and place of articulation. The syllabus types of English and Persian are also cause a lot of problem in spoken language. The differences between word stress patterns in Persian and English also make problematic areas for Iranian students. In this paper, through detailed examination of Persian and English sound systems, some of the specific problems areas have been identified, especially in reference to some of the characteristic phonological differences between the two languages.

Keywords: vowel, consonant, syllable type, stress pattern

\section{INTRODUCTION}

It is now generally acknowledged the term "Intelligibility" as the primary concern for second or foreign language learners (Derwing \& Munro, 2005). Fraser (2000) claims that learners of English as a Second Language (ESL), regardless of the accent they have, need to be able to speak in a way which is easily. The fact that native speakers of English can recognize foreign accents in ESL/EFL learners' speech such as Spanish accents, Japanese accents, Chinese accents, Iranian accents, etc., is a clear indication that the sound patterns or structure of their native languages have some influence on the speech or production of their second language. Avery and Ehrlich, (1992, cited in Ohata, 2004) believe that the foreign accent of non-natives can be due to the influence of their native languages. A foreign accent is the constant occurrence of the phonetic differences from the norms of a language 
which L1 speakers of that language recognize as unfamiliar to their own language sound system (Brown, 2007; Roach, 2009). In other words, it is quite reasonable to say that the nature of a foreign accent is determined to a large extent by a learner's native language (Avery \& Ehrlich, 1992). Thus, the pronunciation errors made by second language learners are considered not to be just random attempts to produce unfamiliar sounds but rather reflections of the sound inventory, rules of combining sounds, and the stress and intonation patterns of their native languages (Swan \& Smith, 1987).

Moreover, the available literature illustrates that English loan words pose certain problems for non-native learners and students of English (Bator, 2010; Swan \& Smith, 2001). A number of researchers have focused specifically on the area of pronunciation and have reported that English loan words present non-native learners and students from different linguistic backgrounds with a number of pronunciation-related problems (Daulton, 2008; Johansson et al., 1999).

In older method, such as audiolingualism, pronunciation has been largely identified with accurate production of isolated sounds or words, and this view is reflected in more contemporary methods such as the Silent Way. The Contrastive Analysis Hypothesis (Lado, 1957) regards pronunciation as central to second language proficiency, but it likewise largely restricts the domain of pronunciation to the segmental level.

Such observation of L2 pronunciation errors, naturally suggests the critical need for ESL/EFL teachers to become more aware of the impact that learners' L1 backgrounds would bring to the learning of English pronunciation. In order to identify specific areas of pronunciation difficulties caused by L1 phonological transfer, teachers need to cultivate a firm understanding of the differences between English and the native language of the learners.

Although contrastive analysis has often been criticized for its inadequacy to predict the transfer errors that learners will make in actual learning contexts, it cannot be easily denied that "such interference does exist and can explain difficulties" (Brown, 1994, p. 200), especially in the phonological aspects of second language learning. In this sense, the significance of contrastive analysis may not necessarily lie in the predictability of transfer errors, but rather in the explanatory potential of learner errors that teachers encounter in their daily practices.

Schachter $(1983,1992)$ has considered the fact that learners may have imperfect knowledge of the second language and she even proposed that transfer is not a process at all, but rather a constraint on the acquisition process. Odlin (1989, p.27) has brought some observations about what transfer is not and concluded that "Transfer is the influence resulting from similarities and differences between the target language and any other language that has been previously (and perhaps imperfectly) acquired". And then he stresses that it is only a working definition. Even recently, Pavlenko and Scott (2002) as cited in Ahmadvand, M. (n.d.) argued that transfer is not unidirectional but bidirectional and simultaneous that is shown by paradigmatic and syntagmatic categories. All this indicates the degree of the complexity of the notion of transfer without any consensus.

\section{SEGMENTAL ASPECTS OF ENGLISH \& PERSIAN}

Vowels

What are the vowels? They are all voiced may be a single like /e/, as in let, or a combination, involving movement from one vowel sound to another like /eI/, as in late; such combination are know as diphthongs, and the combination of three vowel sounds are know as triphtonges like /auə/ in "our". As Yavas (2006) stated there are noticeable expected differences in vowel systems between Persian and English. Comparing the Persian vowel system with that of English reveals some significant differences in the following three areas: 1) the number of vowels, 2) tense/lax distinctions, and 3) the pure/glide (by glide I mean the movement of articulator). In the English vowel system, there are 15 different vowels identified, 
which include several diphthongs such as /aw/, /ay/, and/oy/. The differentiation between tense and lax vowels is made according to how much muscle tension or movement in the mouth is involved in producing vowels (Ladefoged, 1982).

Thus, vowels produced with extra muscle tension are called tense, and vowels produced without that much tension are called lax vowels. For example, /i/ as in English /it/ "eat" is categorized as a tense vowel as the lips are spread (muscular tension in the mouth) and the tongue moves toward the root of the mouth. In Persian we haven't the exact thing, but we can show this by some words; for example, in the two words sib and sini we can notice this difference: for the word sib the vowel is a bit shorter than when we produce the word sini (more duration is needed to pronounce this sound).

It is something similar to gemination, when persons believe that there is no gemination in English, but for example in a word like "bookcase" we can notice the geminating of the sound $/ \mathrm{k} /$ when we pronounce it. On the other hand, /I/ as in English "it" is considered to be a lax vowel as there is little movement of the tongue or muscular tension of the lips involved in its production, compared to the manner in which the tense vowel /i/ as in "eat" is produced. According to the number of vowels, there are apparently more vowels present in English than in Persian. The fact that the Persian vowel inventory is characterized as a typical six-vowel system and in English, there are five front vowels, and five back vowels suggests that Iranian students would have difficulty producing English vowels that do not exist in the Persian vowel system.

There are six vowel sounds in the Persian language. Three are considered long vowels; the other three are short vowels. The three long vowels are $[\mathrm{i}:],[\mathrm{u}]$, and [ $\left.{ }^{\mathrm{a}}\right]$; the three short vowels are [æ], [e], and [o]. There are also two diphthongs: [ei] and [ou]. All of the Persian vowel sounds are the same or very similar to English vowels; however, English has several vowels that do not exist in Persian. These include [i] as in bit, $[\underline{\underline{\Lambda}}]$ as in but, [ $\left.{ }^{v}\right]$ as in book, and [ㅋ] $]$ as in the middle vowel sound in "sympathy". So here it should be mentioned that the teachers should work more on these vowels. And as a method for a teacher is better to use minimal pairs to clarify the differences between pair familiar vowels for students first (by pair vowel I mean /I/ and /I:/ as in words like ship and sheep) and then uses some techniques to teach unfamiliar vowel (it is recommended teachers start with familiar and known vowels which are exist in both languages and their differences and then go through the unknown vowels combinations such a triphthongs).

Persian Vowels

\begin{tabular}{|c|c|c|c|}
\hline $\begin{array}{l}\text { Tongue } \\
\text { Height }\end{array}$ & $\begin{array}{r}\text { Part of Tongue } \\
\text { Front }\end{array}$ & Centre & Back \\
\hline High & \multirow[t]{4}{*}{ i: } & & $\mathrm{u}$ \\
\hline Mid & & & \\
\hline Low & & & o \\
\hline & & & a \\
\hline
\end{tabular}


Amir Toghyani Khorasgani, Ali Toghyani Khorasgani, Narges Keshti Aray

A Survey On Several Potentially Problematic Areas Of Pronunciation For Iranian Efl Learners

English vowel chart for comparison

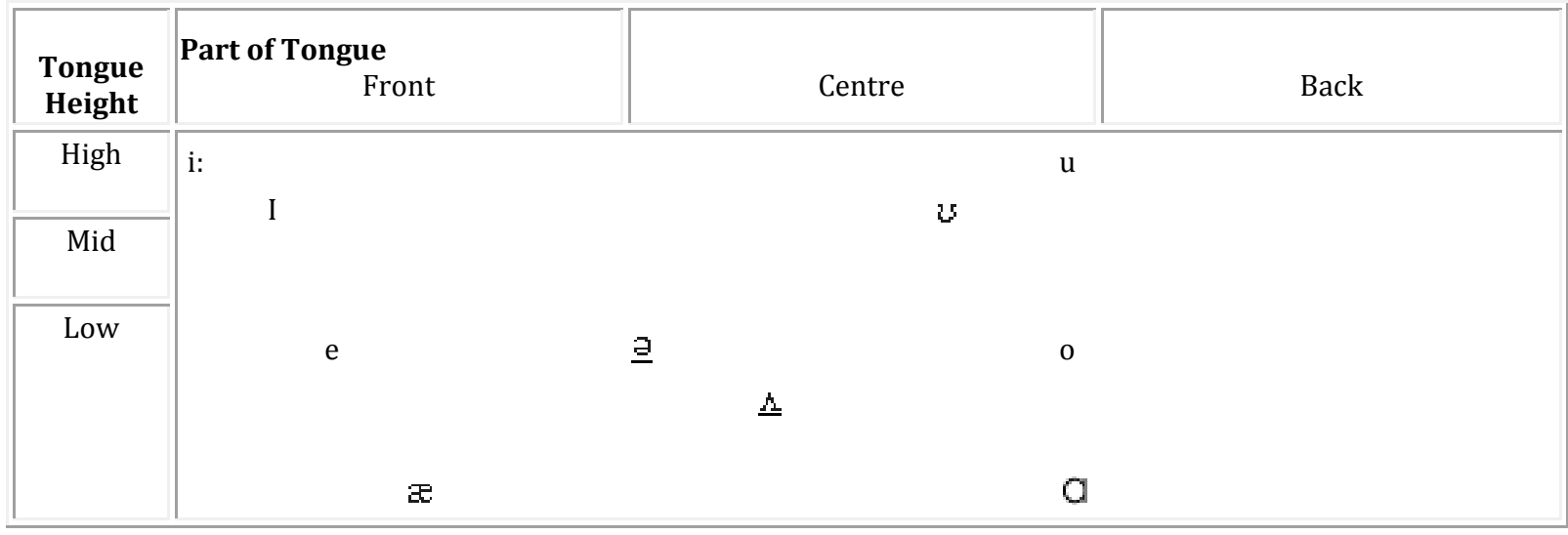

\section{Consonants}

As with the differences in the vowel systems, there are also noticeable differences in consonantal distributions between Persian and English (Yavas, 2006). The tables, which show the consonant systems of English and Persian languages, clearly illustrate the fact that there are more consonants in English. The researcher concluded that as same as the vowel, here for consonants students have face some problems again with those which are not exist in English and those which their pronunciation are different.

Another difference in the consonant is the sound $/ \eta$ / because in Persian we pronounce /g/ after the sound /n/ like: chang, mang, tofang, hang, lang, feshang, here the absence of this unique sound cause the problem and researcher's suggestion is work on this sound as soon as possible from very beginning. For this sound, the absence of this sound in students' native language (Persian) cause to negative transfer from their L1 too; because they search for the nearest equivalence for this sound and find the combinations of the sound /n/ and /g/ as mention above.

Still another difference in the consonantal distribution between Persian and English is that there exist some consonants found in the consonant inventory of Persian but not in that of English and vice versa. For example, in Persian there is /gh/ sound in a word like "bagh" or $/ \mathrm{x} /$ sound in a word like "xanevadeh". Still another difference is that in Persian we have four varieties of the sound $/ \mathrm{z} /$, and three varieties of the sound /s/ which their equivalent in
English is absent. In English we have some consonant sounds like / ฑ́/, /w/, / which are absent in Persian. It should be noted here for an Iranian learner beginner or even advanced students it is difficult to differentiate between /w/ and /v/ automatically when they are speaking in a live speech and it is due to absence of the same differences in Persian.

\section{A CONTRASTIVE CONSONANT LIST}

Consonants that are common in English and Persian are in the first line (level 0-transfe; no differences between English consonants and Persian).

Consonants exclusive to English are in the second line level 4, over differentiated; new consonants in English which are not in Persian).

p, b, t, d, k, g, ?, m, n, r, f, v, s, z, J, 3, h, l, r, j, t , d3. $\theta$, ð,w, y.

Many consonants belonged to both languages, with the exception of $w, \theta$, and $ð$. There are a few existing sounds that is not exist in English (level 2, under differentiation; some consonants are available in Persian which are not in English): Those were the Persian letters; "ghaf" and "ghain" /g/ and also "khe" / /.

The major difference between English and Persian is the incapability of each language's speakers to pronounce the physical requirements of the other language's phonetic alphabet. The researcher encountered many English speakers that 
couldn't pronounce the "ghaf" or "khe" letters of the Persian alphabet. And on the other hand, the researcher encountered Persian speakers who can't pronounce the "th" sound of " $\theta$ " and some cannot distinguish between $/ \mathrm{w} /$ and $/ \mathrm{v} /$ sound as mention before. Each language employs different ends of the spectrum of phonetics.

Here a delicate note should be mentioned; of course Persian has two varieties of /g/ and four varieties of / $/$ / but most of the speakers even literate ones don't know the differences between them due to the pronunciation although these varieties could change the meaning of the word when they are written.

Alveolar stops / $t /$ and /d/ are either alveolar or dental. The unvoiced stops $/ \mathrm{p}, \mathrm{t}, \mathrm{t}$, $\mathrm{k} /$ are aspirated much like their English counterparts: they become aspirated when they begin a syllable, though aspiration is not contrastive. Persian does not have syllableinitial consonant clusters like CCCV in linguistics, a consonant cluster (or consonant blend); it is a group of consonants which have no intervening vowel. In English, for example, the groups' /spl/ and /ts/ are consonant clusters in the word splits. So unlike in English, /p, t/ are aspirated even following /s/, as in /hastam/ "I am"; thus, a word with initial consonant clusters such as "street" may be pronounced as /estIrIt/ or 'student" may be pronounced /estju:dent/. Word like "our" is difficult for Iranian learners because it is one syllabus, a glide vowel. Here I should mention; there are some languages that forbid empty onset such as, Persian, Hebrew, and Arabic (actually begin with semiconsonantic glides or with glottal or pharyngeal consonant, like the word $a b r$ in Persian).

Another problem for Iranian students is syllabus; syllable is a unit of organization for a sequence of speech sounds. For example, the word water is composed of two syllables: $w a$ and ter. A syllable is typically made up of a nucleus (most often a vowel) with optional initial and final margins (typically, consonants). So as we studied before in some words like street, and students, Iranian learners make some syllable errors because of clustering absence in Persian.

In sum, there are 23 consonant sounds in Persian, most of which are also found in English. The velar fricatives [x] and [q] are the only Persian consonants that do not occur in English. Conversely, there are four English consonants that do not exist in Persian. These sounds are the interdentals ${ }^{\theta}$ ] and [ð], as in thigh and thy, the rounded velar glide [w], as in went, and the velar nasal $[\underline{\mathrm{t}}]$, as in the final sound of sing. The differences between the sounds of $/ v /$ and /w/ when an Iranian learner of English is speaking is not considered and most of the times if not always she or he uses / $/$ for both even between advance students (although the advance students are aware of the difference pronunciations of these two sounds, but they mostly never correct it when they are speaking); the researcher approach to this problem from over generalization view. In over generalization view the students over generalize a rule, and here the pronunciation of the sound $/ \mathrm{v} /$, to other places incorrectly, here instead of the pronunciation of the sound /w/.

\section{PERSIAN CONSONANTS}

\begin{tabular}{|c|c|c|c|c|c|c|c|c|}
\hline \multicolumn{1}{|c|}{} & & Bilabial & Labiodental & Alveolar & Palatal & Velar & Glottal \\
\hline \multirow{3}{*}{ Stops } & Voiceless & $\mathrm{p}$ & & & $\mathrm{t}$ & & $\mathrm{k}$ & $\mathbf{Z}$ \\
& Voiced & $\mathrm{b}$ & & & $\mathrm{d}$ & & $\mathrm{g}$ & \\
\hline \multirow{2}{*}{ Fricatives } & Voiceless & & $\mathrm{F}$ & $\mathrm{s}$ & $\mathrm{J}$ & $\mathrm{x}$ & $\mathrm{h}$ \\
\hline & Voiced & & $\mathrm{V}$ & $\mathrm{z}$ & 3 & $\mathrm{q}$ & \\
\hline \multirow{2}{*}{ Affricates } & Voiceless & & & & $\mathrm{t}$ & & \\
\cline { 2 - 9 } & Voiced & & & & $\mathrm{d} 3$ & & \\
\hline
\end{tabular}


Amir Toghyani Khorasgani, Ali Toghyani Khorasgani, Narges Keshti Aray

A Survey On Several Potentially Problematic Areas Of Pronunciation For Iranian Efl Learners

\begin{tabular}{|c|c|c|c|c|c|c|}
\hline Nasals & $\mathrm{m}$ & & $\mathrm{n}$ & & & \\
\hline Liquids & & & $\mathrm{r}, \mathrm{l}$ & & & \\
\hline Glides & & & & $\mathrm{j}$ & & \\
\hline
\end{tabular}

\section{Syllable types}

Comparing several words from

English and Persian can tell us some of the characteristic differences in the way that each language utilizes syllables for forming a word. The English syllable (and word) twelfths /twelf $\theta$ s/ is divided into the onset /tw/, the nucleus $/ \varepsilon /$, and the coda /lf $\theta$ s/, and it can thus be described as CCVCCCC ( $\mathrm{C}=$ consonant, $\mathrm{V}=$ vowel). On this basis it is possible to form rules for which representations of phoneme classes may fill the cluster. For instance, English allows at most three consonants in an onset which is impossible in Persian (it is never be beyond one $\mathrm{C}$ in onset)

From these examples, we can say that English allows a wide variety of syllable types including both open and closed syllables: $\mathrm{CV}$ (open syllable), CVC CCVC, CCVCC, CCCVCC (closed syllable). On the other hand, the syllable types that Persian allows seem to be restricted. Syllable structure is very predictable in Persian; the possibilities are CV ba, CVC baz, and CVCC bast.

We can conclude that some mispronunciation of words like student, split, string, splash, for Iranian are due to consonant clusters, so the Phonotactic constraints are language specific. For example, in Persian, consonant clusters like /st/ are not allowed, although they are in English. Similarly, the sounds / kn/ and /gn/ are not permitted at the beginning of a word in English. So because of this problem Iranian learners' are using to say /estiju:dent/ instead of /stu:d $\mathrm{E}_{\mathrm{nt}} \mathrm{n} / \mathrm{which}$ is totally different from its origin. It causes to some misunderstanding between two speakers (if one of them is native speaker); as a observer, in a conversation with a native who was not familiar with this problem of Iranian speakers and not familiar with the Iranian culture when interlocutor offered him "ice cream" he understood "I scream" and he really was confused and couldn't get the point immediately.

As a method for teaching students to prevent such errors we should first teach our teachers don't such errors (pedagogical effect), and then correct our students immediately after they produce such errors (theses errors are hinder to full understanding).

\section{SUPRASEGMENTAL ASPECTS OF ENGLISH \& PERSIAN}

Suprasegmental aspects of the English sound system such as rhythm, stress, and intonation are often distinguished from the segmental aspects such as consonants and vowels discussed earlier. These suprasegmental aspects of English are also considered to be different from those of Persian in many respects.

Stress

Stress and intonation, the so-called prosodic, or suprasegmental, domain, together with the related coarticulatory phenomena of the blending and overlapping of sounds in fluent speech. Prosodic features involve the relative levels of stress and pitch within syllables, words, phrases, and longer stretches of speech. Coarticulation causes elisions, contractions, and assimilations of neighboring sounds in the stream of speech under the influence of stress and intonation (Ladefoged,1982, pp. 52-56, 98).

Stress refers to the degree of effort involved in the production of individual syllables or combinations of syllables making up a word or longer utterance. For longer utterances a combination of strong and weak syllables comprises a rhythmic pattern. English, like any language, is spoken with a distinct rhythmic pattern.

Rules of word stress 
The researcher makes the differences between word stress patterns in Persian and English to pinpoint the problematic areas for Iranian students.

\section{Rules of word stress in Persian}

One syllable in each word (or breath group) is stressed.

\section{General rule:}

I. Stress falls on the last stem syllable of most words.

Exceptions and clarifications:

II. Stress falls on the first syllable of interjections, conjunctions and vocatives. E.g. /'bale/ "yes", /'nakheir/ "no indeed", /'vali/ "but", /'cerā/ "why", /'agar/ "if", /'mersi/ "thanks", /'xānom/ "Ma'am", /'āqā/ "Sir".

III. Never stressed are: 1) personal suffixes on verbs (-am "I do..", - $i$ "you do..", ... -and "they do..") 2) a small set of very common noun enclitics: the ezāfe (-e/-ye) "of", -rā "[direct object marker]", - $i$ "a, an", - o "and"; 3 ) the possessive and pronoun-object suffixes, - $a m$, et, -esh.
IV. Always stressed are: 1) the personal suffixes on the positive future auxiliary verb; 2 ) the negative verb prefix $n a-/ n e-$, if present; 3 ) if $n a-/ n e$ - is not present, then the first nonnegative verb prefix (e.g. mi- "-ing", bi- "Do!", and the prefix noun in compound verbs (e.g. $k \bar{a} r$ in $k \bar{a} r$ mi-kardam); 3) the last syllable of all other words, including the infinitive ending -an and the participial ending -te/-de in verbal derivatives, noun suffixes like $-i$ "ish" and -egi, all plural suffixes (-hā, $-\bar{a} n)$, adjective comparative suffixes (-tar, -tarin), and ordinal-number suffixes (-om). Nouns not in the vocative are stressed on the final syllable: /xā'nom/ "lady", /ā'qā/ "gentleman".

$\mathrm{V}$. In the informal language the present perfect tense is pronounced like the simple past tense. Only the stress distinguishes between these tenses: the stressed personal suffix indicates the present perfect and the unstressed one the simple past tense which this rule is totally absent in English:

\begin{tabular}{lll}
\hline Formal & Informal & Meaning \\
\hline$d \bar{i}$ 'de- $a m$ & dí'dam & I have seen \\
\hline 'dìdam & 'dìdam & I saw \\
\hline
\end{tabular}

Rules of word stress in English

(Note: the syllables indicated in capitals are the stressed syllables for these English words).

Core vocabulary: many nouns and adjectives of two-syllable length are stressed on the first syllable. For example, SISter, BROther, MOther, WAter, LOvely etc.

Prefix and suffixes: these are not usually stress in English.

QUIetly, deFECtive, and so on.

Exceptions: BIcycle, DISlocate.

Compound verb: words formed from a combination of two words tend to be stressed on the first element: POSTman, NEWSpaper, TEApot, CROSSword etc. Words having a dual role: in the case of the words which can be used as either a noun or a verb, the noun will tend to be stressed on the first syllable and the verb on the last syllable. Examples: IMport(n), imPORT(v). REbel(n), reBEL(v), and INcrease(n), inCREASE(v).

In Persian, word stress is progressive; therefore, it falls on the final syllable of a word, unless the final syllable is a clitic. Phrase stress, however, is regressive; therefore, verbs tend to be stressed on the initial syllable which is totally different in English language. For example, the compound noun baz-kon, which means 'opener,' is stressed on the final syllable, while the verb phrase represented by baz kon, which means 'open,' is stressed on the initial syllable; we have a related but completely different rule in English too. For example, the word import with stress on "port" when it is verb and with stress on "im" when it is noun; the first word, the verb means: to bring it from another 
countries for sale or use; the second, the noun means: something bought and taken into a country from another. The similarity between two languages here is that in both stress pattern change the meaning and part of speech altogether.

Although both English and Persian are similar in having word stress, they differ in terms of how word stress is realized in creating characteristic stress patterns of each language. Most often in English, stressed syllables are marked primarily by making vowels longer and louder, while in Persian syllable stress involves simply saying vowels at a higher pitch. A good method to teach the stress patterns in a foreign language are repetition after a model (it can be a teacher or a tape recorder) for students to internalize and cognize the rules.

\section{SOME OTHER PROBLEMATIC AREAS FOR IRANIAN LEARNERS}

Final rising intonation pattern as used in yes-no question or final rising-falling as used in statements, commands, and whquestions often cause problems for nonnative speakers. For example, even if an Iranian student intends to say a sentence as a statement, a native English speaker might misinterpret the statement as a question or assume that the speaker has not finished speaking yet. This example of misinterpretation as to the intent of the speaker's utterances clearly illustrates one of the most common problems that Iranian learners of English may encounter in communication. When a speaker fails to lower the pitch level far enough at the end of a sentence, the utterance might be perceived as a continuation of the speech, in spite of the speaker's initial intention to finish the line. Furthermore, it should be noted that since pitch changes can convey not only the meaning of sentences but also the speaker's attitude toward a topic of conversation, narrower use of pitch ranges by Iranian students in their speech might be (mis)interpreted as a sign of boredom or lack of interest by the native English speakers.

\section{ACQUISITION PROCESSES IN L2 PHONOLOGY}

Second language acquisition (SLA) research has confirmed that many other processes interact with language transfer in shaping the L2 (second language) phonological system. Some of these acquisition processes are similar to those found in first language phonological development and may be interpreted as a reactivation of first language development strategies. For example, children acquire voiceless consonants before voiced consonants (Macken \& Ferguson, 1981), and the same order of acquisition has been observed in second language phonological development, even when the learner's native language possesses voiced final consonants.

Another phenomenon cited as a developmental process in first and second language acquisition is simplification Largescale simplification of the target language by nonnative speakers has been seen as a kind of pidginization (Ferguson, 1971; Schumann, 1978). For second language learning the pidginization model predicts that a learner's interlanguage forms will either fossilize at some distance from the target or go through a process of decreolization to approximate the target phonology over time.

The teaching of pronunciation must focus on longer term goals; short-term objectives must be developed with reference to long term goals. The goal of any explicit training in pronunciation should be to bring learners gradually from controlled, cognitively based performance to automatic, skill-based performance.

\section{CONCLUSION}

Flege's (2005) Full Access Hypothesis states that the processes and devices that control successful L1 speech acquisition, including the ability to develop new phonetic categories, remain intact across the life span. This means that brain retains its plasticity and ability to change even at adult age.

As we have seen in the preceding sections, many of the potential pronunciation difficulties for Iranian ESL/EFL learners are found to be a clear reflection of the L1 phonological transfer. Through detailed examination of Persian and English sound systems, some of the specific problems areas 
have been identified, especially in reference to some of the characteristic phonological differences between the two languages.

Pronunciation difficulties for Iranian learners of English may arise: 1) When they encounter sounds in English that are not part of the sound inventory of Persian; 2) When the rules of combining consonant sounds into words in Persian are different from those in English (i.e., different consonant cluster); 3) When the characteristic patterns of stress in English, are different from those in Persian; 4) When the stress change both the part of speech and meaning of a word.

It should be noted, however, that identifying specific pronunciation difficulties for Iranian learners of English do not necessarily lead to the dramatic improvement of their pronunciation, but rather that such knowledge can only constitute a prerequisite for teachers in creating actual teaching activities. Teachers of English as a second/foreign language are now believed to have a more enabling role in the classroom (Chang, 2007; Kumaravadivelu, 2012, Nosratinia \& Zaker, 2013a, 2013b). In other words, whether pronunciation teaching can become effective or not largely depends on how teachers can utilize such knowledge in designing the teaching materials or activities that help students become aware of the differences between English and Persian sound systems and improve their pronunciation by themselves (Kelly, 2000; Celce-Murcia, Brinton \& Goodwin, 1996). Although it is almost a cliché that the better the pronunciation, the more effective the communication becomes, it is equally true that even if L2 learners could attain perfect pronunciation of separate sound items, that does not guarantee smooth communication with native speakers nor effective presentation of the ideas that they intend to convey. Communicative aspect of language learning, which involves many other competence requirements such as grammatical, strategic, sociolinguistic, or discourse knowledge, should not be neglected for the sake of native-like accuracy of pronunciation (Morley, 1987; Celce-Murcia, 1987). Teaching should aim toward gradually reducing the amount of native language influence on segmental, voice-setting, and prosodic features but should not necessarily seek to eradicate totally the influence of the native language on the speaker's pronunciation in the second language. Pronunciation ought to be taught as an integral part of oral language use, as part of the means for creating both referential and interfactional meaning, not merely as an aspect of the oral production of words and sentences.

Pronunciation forms a natural link to other aspects of language use, such as listening, vocabulary, and grammar; ways of highlighting this interdependence in teaching need to be explored.

\section{REFERENCES}

Ahmadvand, M. (2015). Analysing Errors of Iranian EFL Learners in Their Written Productions. Retrieved 12 14, 2008, from Knol Beta: A unit of knowlede: http://knol.google.com/k/moslemahmadvand/analysing-errors-of-iranian-efl/ tbh5kkwy5hmk/2?locale=en.

Avery, P. \& Ehrlich, S. (1992). Teaching American English pronunciation. Oxford: Oxford University Press.

Bator, M. (2010). Obsolete Scandinavian loanwords in English. Frankfurt: Peter Lang.

Brown, H. D. (1994). Principles of language learning and teaching (3rd ed.). Englewood Cliffs, NJ: Prentice Hall.

Brown, H. D. (2007). Principles of language learning and teaching (5th ed.). New York: Pearson Education.

Catford, J. C. (1977). Fundamental problems in phonetics. Edinburgh: Edinburgh University Press.

Celce-Murcia, M., Brinton, D., \& Goodwin, J. (1996). Teaching pronunciation: A reference for teachers of English to speakers of other languages. Cambridge: Cambridge University Press.

Chang, Y. L. (2007). The influence of group process on learners' autonomous beliefs and behaviors. System, 35 (3), 322-337.

Daulton, F. (2008). Japan's built-in lexicon of Englishbased loanwords. New York: Multilingual Matters.

Derwing, T. M., \& Munro, M. J. (2005). Second language accent and pronunciation teaching: A researchbased approach. TESOL Quarterly, 39, 379-397.

Flege, J. E. (2005). Evidence for plasticity in studies examining second language speech

acquisition. Workshop held at ISCA Workshop on Plasticity in Speech Perception, London, UK.

Fraser, H. (2000). Coordinating improvements in pronunciation teaching for adult learners of English as a second language (Gov. Rep.). Canberra: DETYA (ANTA Innovative Project). 
Johansson, S., Hasselggard, H., \& Oksefjell, S. (Eds.). (1999). Out of corpora: Studies in honor of Stig Johansson. The Netherlands: Rodopi.

Kelly, G. (2000). How to teach pronunciation. Essex: Longman.

Kumaravadivelu, B. (2012). Language teacher education for a global society: A modular model for knowing, analyzing, recognizing, doing, and seeing. New York: Routledge.

Ladefoged, P. (1982). A course in phonetics. New York: Harcourt Brace

Macken, M. A., \& Ferguson, C. A. (1981). Phonological universals in language acquisition. Annals of the New York Academy of Sciences, 379, 110-129.

Nosratinia, M., \& Zaker, A. (2013, April). Creativity and autonomy: Connections for language learning. Paper presented at the Second ELT Conference, Allameh Tabataba'i University, Tehran, Iran.

Nosratinia, M., \& Zaker, A. (2013, August). Autonomous learning and critical thinking: Inspecting the association among EFL learners. Paper presented at the First National Conference on Teaching English, Literature, and Translation, Shiraz University, Shiraz, Iran.

Odlin, T. (1989). Language Transfer, Cambridge: Cambridge University Press.
Ohata, K. (2004, October 20). Phonological Differences between Japanese and English, retrieved, 14 Dec 2008, from Resource Center For Vietnamese Students of English: http://khoaanh.hcmup.edu.vn/index.php?name $=N$ ews\&file $=$ article\&sid $=608$

Pavlenko, A. and Scott, J. (2002). "Bidirectional Transfer", Applied Linguistic, 23, 2, pp: 190-214.

Roach, P. (2009). English phonetics and phonology: A practical course (4th $\mathrm{ed}$.). Cambridge: Cambridge University Press.

Schachter, J. (1983). "A new account of language transfer", in S. Gass and L. Selinker (eds.), Language transfer in language learning. Rowley, MA: Newbury House, pp.98-111.

Swan, M., \& Smith, B. (Eds.). (1987). Learner English: A teacher's guide to interference and other problems. Cambridge: Cambridge University Press.

Swan, M., \& Smith, B. (2001). Learner English: A teacher's guide to interference and other problems, (Vol. 1). United Kingdom: Cambridge University Press.

Yavas, M. (2006). Applied English phonology. Malden: Blackwell. 